\title{
The Countermeasures Research on the Issues of Enterprise Financial Early Warning System
}

\author{
Qian Luo ${ }^{1} \&$ Xilin Liu $^{2}$ \\ ${ }^{1}$ School of Management, Shanghai University of Engineering Science, Shanghai, China, research direction: \\ Financial Management and Capital Market. \\ ${ }^{2}$ School of Management, Shanghai University of Engineering Science, Shanghai, China, Head of Investment Finance \\ Department, Associate Professor, Chief Economist, Chief Accountant, research direction: Financial Management and \\ Capital Market. \\ Correspondence: Qian Luo, Wenhui Road 800 Lane, The 56th building, Room 306. Songjiang University Town, \\ Songjiang District, Shanghai, China. E-mail: 438453100@qq.com/luoqianjj@yeah.net
}

Received: November 6, 2013

Accepted: November 15, $2013 \quad$ Online Published: November 20, 2013

doi:10.5430/afr.v2n4p166

URL: http://dx.doi.org/10.5430/afr.v2n4p166

\begin{abstract}
In order to ensure the normal production and operation of enterprises and the realization of business objectives, enterprises must establish an effective financial early warning system. A scientific enterprise financial early warning system that can prevent and defuse the crisis in time provides a beneficial help for the favorable business decisions of enterprise. Based on the research of enterprise financial early warning system, this paper points out how to build an effective financial early warning system, analyzes the existing problems in the current application of enterprise financial early warning systems, and puts forward a number of countermeasures and suggestions for the effective use of financial early warning systems, which has a certain practical significance.
\end{abstract}

Keywords: Financial risk, Financial warning, Early warning system

\section{Introduction}

This article is devoted to the issues of dealing with the financial risk of enterprises. The current global financial crisis proved that even the best international companies must constantly monitor their financial situation and those of companies with which they cooperate. The globalization process has led to the emergence of a complex network of relationships in the business environment. In a market economy, this means increased complexity and uncertainty of phenomena affecting the financial standing of entities. No company, even during a period of prosperity, can be certain of its future. The global financial crisis, which began in the second half of 2008, caused the number of companies in danger of bankruptcy to significantly increase around the world. The overall increase of bankruptcy risk in companies around the world has increased the awareness of the need to implement methods for providing early warning to enterprises against financial risk. Therefore, the earlier warning signals need to be detected, the more time managers will have for preparing and reacting in subsequent phases of the crisis.

In this article, the author gives the countermeasures to the issues of enterprise financial early warning system. Section 2 describes the main bottlenecks in the application of enterprise financial early warning system in China. Section 3 introduces the improvement and enhancement of early warning efficiency. In Section 4, the author presents all countermeasures and Suggestions for the effective operation of warning system .Section 5 is devoted to conclusions from the presented research.

\section{Bottlenecks in the application of enterprise financial early warning system in China}

\subsection{Lack of early warning awareness}

Currently the majority of our business is in a period of rapid development, companies are growing fast, however, the corresponding financial early warning system construction is lagging, even though some companies have established the financial early warning system, there still exist many limitations in the process of practical application, mainly reflected in: On the one hand, the overall development of China's macroeconomic trends is getting better, many enterprises have developed rapidly, the profitability is generally high in many industries, therefore, the risk prevention awareness in most enterprises is not strong, decision-making, management and employees lack the 
motivation to actively use and concern the financial early warning system. On the other hand, most enterprises in our country are still in relatively low level stage in the research and application of the financial early warning system, financial early warning system's contribution to the enterprise is difficult to get fully reflected, that is relevant to the lack of the consciousness of the use of financial early warning system in decision-making and management.

\subsection{Lack of the use of targeted warning model}

From the perspective of enterprise, a qualified warning system should be able to provide accurate and timely early warning information for managers according to the actual situation of the enterprise. The financial risk early warning system model should be based on different characteristics and needs of the different enterprises, in order to develop its pertinence and maneuverability. However, nowadays, many listed companies' financial risk early warning system is seriously out of a listed company's actual situation, the accuracy of the early warning model is low, it is difficult to guarantee the truthfulness, accuracy of enterprise financial risk early warning information.

\subsection{Separation between warning system and management information system}

At present, many enterprises have established the corresponding financial early warning system, but the early warning system and the management information system are in a state of mutual independence in many enterprises, in the meanwhile, most enterprises do not pay attention to the effective combination of both, so the financial early warning system is not unable to accurately predict corporate financial risk. The accuracy and efficiency of the financial early warning signal is relatively poor with lack of support from the management information system. The effective functioning of the financial early warning system needs to be based on two auxiliary systems, in particular to strengthen the construction work of the two auxiliary information systems.

\subsection{Lack of follow-up management tools and methods}

At present, many enterprises only attach importance to the pre-building work of the financial early warning system, paying no attention to the follow-up warning system management and maintenance, enterprise lacks of summarizing the experiences and lessons from the financial risk events that are treated by the financial early warning system, can not improve and update the financial early warning system in time, can not provide effective experience for reference for the future management and prevention of financial risks, what is more, the enterprise lacks of the follow-up management of the financial early warning system.

\section{Improvement and enhancement of early warning efficiency}

Enterprises should build financial early warning system which is based on scientific, systematic, cost-benefit balance, dynamic principles.

\subsection{Perfect warning index system structure}

Enterprise financial early warning index system are available from short-term solvency, long-term solvency, operating capacity, profitability, price ratio and other indicators to determine, financial risk early warning model can be expressed as: $\mathrm{G}=\mathrm{Gi} * \mathrm{Wi}$. $\mathrm{G}$ for the company's comprehensive effect coefficient, $\mathrm{Gi}$ for effect coefficient for a single variable, Wi for weight.

Table 1. Financial early warning index system(quantitative indicators)

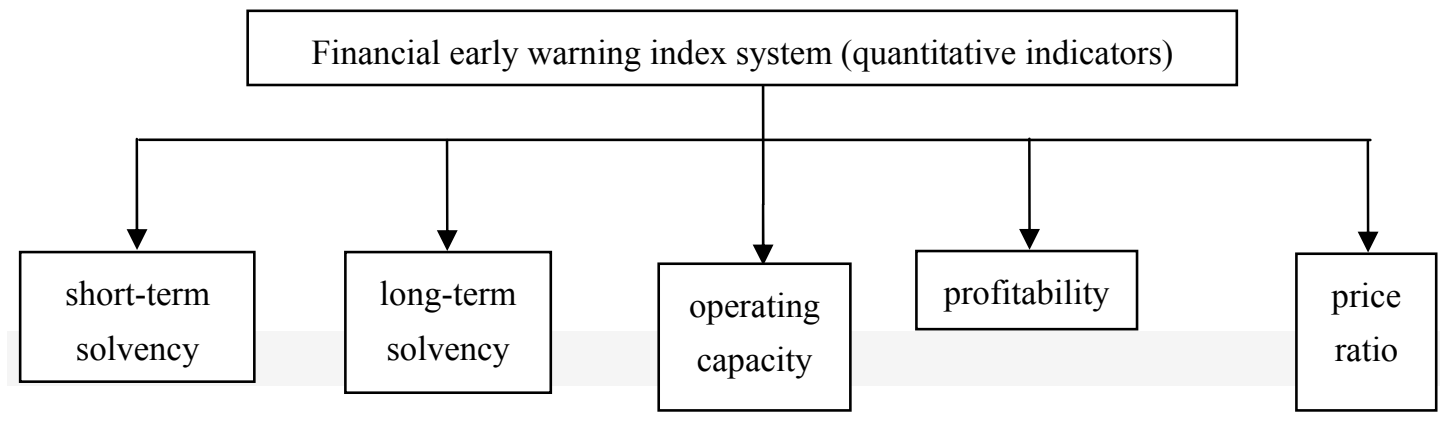

The financial early warning index system includes the above aspects. They are short-term solvency, Long-term solvency, operating capacity, profitability, price ratio. 
Table 2. Financial early warning index system (quantitative indicators)

\begin{tabular}{|c|c|}
\hline $\begin{array}{l}\text { Short-term } \\
\text { solvency }\end{array}$ & $\begin{array}{l}\text { Working capital }=\text { current assets }- \text { current liabilities } \\
\text { Current ratio }=\text { current assets } \div \text { current liabilities } \\
\text { Quick ratio }=\text { liquid assets } \div \text { current liabilities } \\
\text { Cash ratio }=\text { (monetary capital }+ \text { tradable financial assets }) \div \text { current liabilities } \\
\text { Cash flow ratio = operating activities net cash flow } \div \text { current liabilities }\end{array}$ \\
\hline $\begin{array}{l}\text { Long-term } \\
\text { solvency }\end{array}$ & $\begin{array}{l}\text { Asset-liability ratio }=(\text { total liabilities } \div \text { total assets }) \times 100 \% \\
\text { Equity ratio }=\text { Total liabilities } \div \text { Shareholders' equity } \\
\text { Equity multiplier }=\text { Total assets } \div \text { shareholders' equity } \\
\text { Long-term capital debt ratio }=\text { [Non-current liabilities } \div \text { (non-current liabilities }+ \\
\text { shareholders' equity }) \times 100 \% \\
\text { Interest coverage ratio }=(\text { net profit }+ \text { interest expense }+ \text { income tax expense }) \div \text { interest } \\
\text { expense } \\
\text { Cash flow coverage ratio }=\text { operating cash flow } \div \text { interest expense } \\
\text { Cash Flow debt ratio }=(\text { operating activities net cash flow } \div \text { total debt }) \times 100 \%\end{array}$ \\
\hline $\begin{array}{l}\text { Operating } \\
\text { capacity }\end{array}$ & $\begin{array}{l}\text { Accounts receivable turnover ratio }=\text { sales revenue } \div \text { accounts receivable } \\
\text { Inventory turnover ratio }=\text { sales income } \div \text { inventory } \\
\text { Current assets turnover ratio }=\text { sales income } \div \text { current assets } \\
\text { Working capital turnover ratio }=\text { sales income } \div \text { working capital } \\
\text { Non-current assets turnover ratio }=\text { sales income } \div \text { non-current assets } \\
\text { Total asset turnover ratio }=\text { sales income } \div \text { total assets }\end{array}$ \\
\hline Profitability & $\begin{array}{l}\text { Sales net profit } \text { rate }=(\text { net profit } \div \text { sales income }) \times 100 \% \\
\text { Total assets Net profit rate }=(\text { net profit } \div \text { total assets }) \times 100 \% \\
\text { Equity net profit rate }=(\text { Net profit } \div \text { shareholders' equity }) \times 100 \%\end{array}$ \\
\hline Price ratio & $\begin{array}{l}\text { PE ratio }=\text { market Value Per Share } \div \text { Earnings per share } \\
\text { PB ratio }=\text { market Value Per Share } \div \text { Net assets per share } \\
\text { PS ratio }=\text { market Value Per Share } \div \text { Sales income per share }\end{array}$ \\
\hline
\end{tabular}

The financial early warning index system includes short-term solvency, long-term solvency, operating capacity, profitability, price ratio. At the same time, the short-term solvency is mainly manifested in working capital, current ratio, quick ratio, cash ratio, cash flow ratio, and long-term solvency, operating capacity, profitability, price ratio are also manifested in several aspects.

\subsection{Determine critical values of warning indicators}

The critical value of financial early warning system is the quantitative criteria of judging enterprise financial risk, and the key of establishing enterprise financial early warning model. To determine the critical value of the financial early warning indicators, the following factors must be taken into account comprehensively: the historical level of each index in enterprise, the average level of industry, the existing level of outstanding enterprises in the industry, the status of the enterprise in the industry, the life cycle of enterprise, enterprise's long-term planning objectives etc, by above, determine the appropriate critical value for the enterprise, then put the above index critical value weighted to get a average summary which reflects the total critical value of the enterprise. It should reflect the policy and science, pay attention to the unity and coordination, also should guarantee the adjustability and stability of the critical value of indicators When determining the critical value. 


\subsection{Determine warning index weight in accordance with the principle of prudence}

After selecting the appropriate financial early warning indicators, it should further determine the intrinsic relationship between the indicators-that is, to define the share of the indicators in the comprehensive score. The author thinks that the Delphi Method (Delphi Method) is more operable. In the expert consultation of weight allocation, arithmetic mean is commonly used in the representative of centralized experts opinions, namely evaluate the index weights, then it should reflect the arithmetic mean of the index weights that the expert panel has scored, in order to understand the degree of dispersion of opinions among experts, we can calculate the dispersion coefficient, it explains the opinions of the experts more consistent when the dispersion coefficient is smaller. This method has overcome the disadvantages in the previous meeting of experts that Experts can not fully express their views, the views of authority figures are above the opinions of the others, the Delphi Method (Delphi Method) has wide representativeness and practicability, so the conclusion by it is more reliable.

\subsection{Effective use of comprehensive effect coefficient}

In the daily management of financial early warning risk, the enterprise should periodically or dynamically compare the early warning index with its critical value, if the early warning index is near or has broken through its critical value, and an alert is necessary depending on the specific situation, by changing the control parameters and variables of financial systems, regulating the financial resource allocation of enterprise in time, the enterprise can make the abnormal changes controlled effectively, so that changes in the financial situation always run within reasonable confidence interval. Alert is necessary in the case of early warning indicator exceeding its critical value, enterprises should immediately issue a financial risk control instruction, take corresponding measures to reduce the risk of losses to the enterprise. Processing scheme must be established in advance, thus weakening the negative impact of financial risk, so as to prevent the recurrence of similar financial risk when companies want to get rid of the negative impact of the financial risk.

\section{Countermeasures and Suggestions for the effective operation of warning system}

\subsection{Foster a sense of financial risk}

Consciousness of risk prevention and early warning is the precondition for the successful implementation of financial early warning system, thus the enterprise employees, especially managers should constantly strengthen the awareness of financial early warning risk and improve the level of risk management. Financial risk exists in all aspects of financial operations, any link failure could lead to financial risk, therefore, enterprises should actively carry out risk avoidance and prevention to improve the overall level of risk. Enterprise financial personnel should keep risk prevention concept throughout the financial work, always keep a clear understanding and high alert for potential financial crisis, master the risk occurrence and variation, and estimate the possible impact of financial risk, strengthen the risk prevention awareness, in order to control the financial risk in the bud and make the correct financial decisions.

\subsection{Establishment and improvement of warning system}

The prediction accuracy of financial early warning model is influenced by many factors. The United States, Japan and other countries have a lot of successful cases about the application of financial early warning model. Enterprises should actively draw lessons from foreign financial early warning system that has been successfully developed and applied on the basis of considering and analyzing the industry environment and enterprise's own characteristics, and further improve the enterprise's financial early warning model and its integration innovation. The enterprise should ensure the universal applicability of financial early warning model, in the meanwhile, should also improve its prediction accuracy. Therefore, enterprise needs to further research and develop a specialized model for its own, and periodically evaluate its effectiveness, to master the validity and accuracy of financial early warning model. The enterprise should improve and update the model, focus on the evaluation index, then predict the potential risks and take preventive measures effectively to prevent financial crisis according to the change of the evaluation index.

\subsection{Effective combination of warning system and management system}

Financial early warning system must be based on a lot of information, which requires the financial early warning system to be combined with the management information system. Management information system provides the data interface for early warning system, establishes channels of communication between early warning system and various subsystems of the enterprise, so the financial early warning system could accurately get enterprise's business information from relatively open information repository, that could provide comprehensive, accurate and timely financial information for the financial early warning system, in order to better predict enterprise financial risk, and then to effectively control risk. 


\subsection{Establish and perfect warning risk fund}

The enterprise should properly arrange the revenue and expenditure activities of the monetary fund according to the size of the capital movement and the characteristics of the production and business operation. Through the establishment of enterprise risk fund, for a financial risk that happen a big contingency and has limited loss, The enterprise should extract a certain amount of monetary fund independent of the enterprise operating fund, that can as a compensation fund when the loss occurs, the risk fund can prevent financial risk from influencing the normal operating fund of enterprise, then to ensure the normal business activities.

\subsection{Strengthening of daily maintenance and information monitoring}

Through the routine maintenance and supervision of enterprise's financial early warning system, it could ensure the data interface smoothly and full of data share between the financial early warning system and other systems such as accounting management information system and related business information collection and analysis system. what's more, it could update financial data financial indicators and early warning thresholds to ensure the early warning timely, accurate and effective. On the basis of above, enterprise should take measures to strengthen the anti virus invasion, hackers steal prevention and illegal operation prevention of the financial early warning system database, to ensure the security and completeness of the database, at the same time, timely and targeted solve the problems found. Enterprise should also pay attention to the collaboration between different departments, establish a comprehensive financial early warning concept and awareness, strengthen the financial early warning system for daily maintenance and comprehensive supervision, improve the effectiveness of risk control of financial early warning system.

\section{Conclusions}

The conclusions from the above research are very important. The research conducted showed that financial early warning system is a technique of analysis that is used to predict the achievement condition of enterprises and to decrease the risk of financial distress. By the application of this technique of analysis, the condition and possible risks of an enterprise can be identified with quantity. The financial crisis has pushed all firms to active risk management and control financial risks. All enterprises need financial early warning system to warn against risks and prevent from financial distress. Benefits of a financial early warning system can summarize as early warning before financial distress, road maps for good credit rating, better business decision making, and greater likelihood of achieving business plan and objectives. Developing practical solutions will not only help to enterprises but also to the economies of countries. Having information about their financial risk, monitoring this financial risk and knowing the required roadmap for the improvement of financial risk are very important for enterprises to take the required precautions. So, it is worth developing a financial early warning system based on financial risk.

\section{References}

Chao Qin, Yunchen Wang. (2009). Review on Enterprise financial early warning at home and abroad. China Management Informationization. 2009(5).

Chen, J., Zhang, J. (2006). Financial distress prediction in China. Review of Pacific Basin Financial Markets and Policies 9 (2), 317-336. http://dx.doi.org/10.1142/S0219091506000744

Guojiang Xu. (2011). The application and improvement of enterprise financial early warning mechanism under the new situation. Special zone economy, 2011(6).

Jialei Li. (2011). The problems and coping strategies of enterprise financial early warning management. China Township Enterprises Accounting, 2011(08).

Jie Shu.Try to talk about the concept of financial early warning theory and its theoretical basis[J].New Finance Economics,2011(10).

Jun Zhou. (2008). The problems and suggestions in the construction and use of financial early warning model in China's enterprises, Journal of jinling institute of technology, 2008.12.

Junde He, Niansheng Zhang. (2009). Research on financial risk early warning based on the modern financial theory. Scientific and technological progress and countermeasures, 2009(2).

Koyuncugil, A. S., \& Ozgulbas, N. (2007a). Developing financial early warning system via data mining. In Proceedings Book of 4th Congress of SMEs and Productivity, Istanbul, pp. 153-166.

Koyuncugil, A. S., \& Ozgulbas, N. (2009b). An intelligent financial early warning system model based on data mining for SMEs. In Proceedings of the International Conference on Future Computer and Communication, Kuala Lumpur, Malaysia. http://dx.doi.org/10.1109/ICFCC.2009.118 
Lin, L., Piesse, J. (2004). Identification of corporate distress in UK industrials -a conditional probability analysis approach. Journal of Applied Financial Economics (14),73-82. http://dx.doi.org/10.1080/0960310042000176344

Mingde Xu. (2010). The discussion about the construction of the Company's financial early warning system. Coastal Enterprises and Science \& Technology, 2010(01):88-89.

Pang-Tien, L., Ching-Wen, L., Hui-Fun, Y. (2008). Financial early-warning models on cross-holding groups. Journal of Industrial Management \& Data Systems 108 (8),1060-1080. http://dx.doi.org/10.1108/02635570810904613

SOI Tax Stats - Individual Statistical Tables by Size of Adjusted Gross Income. (n.d.). Internal Revenue Service. Retrieved May 2, 2013, from http://www.irs.gov/uac/SOI-Tax-Stats---Individual-Statistical-Tables-by-Size-of-Adjusted-Gross-Income

Wei Zhang. (2009). The comparative analysis of enterprise financial early warning models, China's high-tech enterprises. 13th, 2009.

Xingze Wu. (2011). Financial crisis and Warning research: Problems and frame reconstruction. Accounting Research, 2011(2):59-65.

Xuanmin Zhao. (2009). Comments on Financial Crisis Warning Model. Communication of Finance and Accounting. 2009(8).

Ying Liu. (2011). Thing about the problems of enterprise financial crisis warning. Commercial Times, 2011(15): :57-58.

Yingbin Kang. (2011). Introduction to the establishment of the enterprise financial early warning system. Guide to Business, 2011,(12).

Yong Zhou. (2010). The Suggestions and application of enterprise financial risk early warning. Business Forum, 2010(9). 